\title{
Predicting green product purchase: Applying a Cognitive-Affective-Behavior hierarchy
}

\author{
Michael Rusiviro Jacob, Yizzy Weny Putri, Sabrina Oktaria Sihombing* \\ Business School, Universitas Pelita Harapan, Tangerang, Indonesia \\ ${ }^{*}$ Corresponding author: sabrina.sihombing@uph.edu
}

\begin{abstract}
There are three major elements that considered being the expected certainty in green product purchasing is environmental attitude, product attitude, and also purchasing intention. Other variables such as collectivism, individualism, subjective and objective knowledge, environmental awareness, government's role, media exposure, social influence, and perceived monetary value are linked to these factors as well. This research aims to examine regarding Indonesian consumers' in creating green product purchase intention by applying Cognitive-Affective-Behavior hierarchy This study used convenience sampling as the design of the sampling with 262 respondents as the sample size. Questionnaires were distributed by spreading through internet and social media. After the data of all respondents were collected, then the analysis process of the data is conducted by using SEM PLS. However, there were seven hypotheses that showed unsupported results. These hypotheses are relationship between collectivism and environmental attitude, individualism and environmental attitude, individualism and product attitude, objective knowledge and environmental attitude, the role of government and product attitude, media exposure and environmental attitude, environmental attitude and purchase intention.
\end{abstract}

Keywords: Green product, cognitive, affective, behavior

JEL Classification Code: M39 DOI: 10.20885/jsb.vol24.iss2.art1

\section{Introduction}

It is well known that there are human activities that could affect the environment in a negative way. These include the increase of carbon emission, the depletion of natural resources, deforestation, and destruction of the ozone layer (Mittal and Mittal, 2013). The global concern regarding these destructive changes has been reflected in several studies that related to people's knowledge and behavior towards environmental, preserving the environment, and buying attitude of environmentally-friendly products. Several studies showed that there is an increasing in global awareness of negative human effects towards the environment (Khaola, Potiane \& Mokhethi, 2014). Awareness of the depletion of natural resources and the destruction of it from human activities has raised some issues about environmental protection and consciousness in the behavior of consumers worldwide.

This has enhanced the amount of demand for green products in the worldwide market. At this time, companies that apply green products are increasingly developing to attract consumer's interest in these products. The company's efforts can influence consumers to have awareness and buy products that are environmentally friendly (Okada \& Mais, 2010; Saxena \& Khandelwal, 2012). In general, consumer awareness consists of consumer perception and consumer reaction. Consumer awareness environment drive their consumption behavior of green products in addition to influencing purchase intention (Wu \& Chen, 2014), can also help preserve the balance of environment sustainability (Okada \& Mais, 2010). Studies on consumer perceptions and purchase intention of a product by applying the green concept have been pointed out by many researchers. Patel and Chugan (2015) stated that consumer perceptions influence the purchase intention. The same thing was revealed by the results of research by Wu and Chen (2014) that consumer awareness of greenbased products and promotions had a significant positive effect on perceived quality and buying interest. This indicates that consumers' positive perception of green products will be a reinforcing factor in purchase intention. 
The result of past research about consumer purchase behavior concludes that the raising of consumer's concern about the environment has given impact to their purchasing behavior; they prefer to buy and consume products that are environmentally beneficial (Sharma, Sonwalkar \& Kapse, 2013). Due to the rising environmental concern, in marketing strategies, the information about features of the product, product quality, brand equity, price, safety and health that are associated with the product are provided to consumers, this information is taken by consumers into account. Despite from all the variables that influence the purchase intention of environmentally friendly products, in the last decade, there have only been a number of similar studies that suggested a relationship between the role of government to purchase intention as shown in Table 1. This table shows gaps that need to be fulfilled. Specifically, the researchers have collected studies that have variables that affect purchase intention, but of the eleven studies, only one study was able to fully explain the relationship of all these variables to purchase intention

Therefore, this study examines how other attributes such as environmental behavior and product attitudes, perceived monetary value and social influence consumer purchase intentions for green products in Indonesia and to see whether cognitive values (collective and individual), individual environmental literacy (goals and subjective knowledge and environmental awareness) and extrinsic motivational attributes (the role of government and media exposure) influence attitudes towards the environment and also green products. This study considers the initiative of Indonesian customers towards environmentally friendly products.

\section{Literature Review}

Table 1 presents different variables that affect purchase intention of green products derived from previous studies. The variables analyzed are as follows: Collectivism (CO), Individualism (IN), Objective Knowledge (OK), Subjective Knowledge (SK), Environmental Awareness (EN), Government's Role (GR), Media Exposure (MED), Social Influence (SIN), Perceived Monetary Value (PMV), Environmental Attitude (ENT), Product Attitude (PRA).

Table 1. Variables that Affect Purchase Intention from Several Studies in a Decade

\begin{tabular}{|c|c|c|c|c|c|c|c|c|c|c|c|}
\hline Previous Researchers & $\mathrm{CO}$ & IN & $\mathrm{OK}$ & SK & EN & GR & ME & SI & PM & EA & PA \\
\hline Sreen, Purbey \& Sadarangani (2018) & $\checkmark$ & & & & & & & & & $\checkmark$ & \\
\hline Samarasinghe (2012) & $\checkmark$ & $\checkmark$ & $\checkmark$ & & $\checkmark$ & & & $\checkmark$ & & $\checkmark$ & \\
\hline Sharma and Aswal (2017) & $\checkmark$ & & & & $\checkmark$ & & & & & $\checkmark$ & \\
\hline $\begin{array}{l}\text { Noor, Jamil, Mat, Mat, Kasim, Mu- } \\
\text { hammad \& Salleh (2012) }\end{array}$ & & & & $\checkmark$ & $\checkmark$ & & & & & $\checkmark$ & \\
\hline $\begin{array}{l}\text { Mamun, Fazal, Ahmad, Yacoob \& } \\
\text { Mohamad (2018) }\end{array}$ & & & $\checkmark$ & & $\checkmark$ & & & & & $\checkmark$ & $\checkmark$ \\
\hline Wulandari, Rahyuda \& Yasa (2015) & & & & $\checkmark$ & & & & & & $\checkmark$ & \\
\hline $\begin{array}{l}\text { Kianpour, Anvari, Jusoh \& Othman } \\
\text { (2014) }\end{array}$ & & & $\checkmark$ & $\checkmark$ & $\checkmark$ & & $\checkmark$ & $\checkmark$ & & & \\
\hline $\begin{array}{l}\text { Kaufmann, Hans, Panni \& Orphanidou } \\
\text { (2012) }\end{array}$ & $\checkmark$ & & $\checkmark$ & & $\checkmark$ & & & & & $\checkmark$ & \\
\hline $\begin{array}{l}\text { Setyawan, Noermijati, Sunaryo \& } \\
\text { Aisjah (2018) }\end{array}$ & & & & $\checkmark$ & & & & & & & $\checkmark$ \\
\hline Maichum, Parichatnon \& Peng (2017) & & & & & $\checkmark$ & & & & & $\checkmark$ & \\
\hline Chen, Chen \& Tung (2018) & $\checkmark$ & $\checkmark$ & $\checkmark$ & $\checkmark$ & $\checkmark$ & $\checkmark$ & $\checkmark$ & $\checkmark$ & $\checkmark$ & $\checkmark$ & $\checkmark$ \\
\hline
\end{tabular}

Source: Prepared by the authors 


\section{Purchase Intention}

Intention is defined as the commitments and decision that stimulate and drive the consumers' purchases of certain product and services (Haque, Anwar, Yasmin, Sarwar, Ibrahim \& Momen, 2015). The common approach to obtain consumer's actual behavior towards products is by understanding their intentions. The intention shows the level of consumer willingness and effort to buy the product (Haque, Anwar, Yasmin, Sarwar, Ibrahim \& Momen, 2015). An intention instructs an individual how to behave and act in a certain way; it implies what they should do, what they are going to do and what they will do. Specifically, purchase intention can be defined as a situation in which consumer tends to purchase a certain kind of product in a certain condition (Mirabi, Akbariyeh \& Tahmasebifard, 2015). Another meaning of purchase intention is the degree of intention that a consumer has like thinking, wanting, and likely to purchase (Baiquni \& Ishak, 2019).

Purchase intentions have a role in consumers' cognitive behavior, that exhibit how an individual's intention acts in their way to purchase a product. (Pei Kian, Boon, Wee \& Yeow, 2017; Takaya, 2019). When consumers can gain new information by consuming or using a product or service, and purchase the product at good prices in transactions has proven able to increase consumers' purchasing intention (Samadi, Lan \& Yin-Fah 2015). When consumers select products, the final decision on whether to buy the product or rejecting it depends on consumers' purchase intention (Madahi and Sukati, 2012). Purchase intention gives exposure to consumers' possibility and willingness to purchase environmentally friendly products compared to conventional products (Nia, Rinawati, Hery \& Bayu, 2018). Furthermore, consumer's intention will affect and drive consumers' decision to purchase a product (Jaafar, Lalp \& Naba, 2012). From the prior study about purchase intentions (i.e., Chen, Chen \& Tung (2018), it can be concluded that there are main factor affecting purchase intentions. In this study, researchers emphasize collectivism, individualism, objective and subjective knowledge, environmental awareness, the Government's role, media exposure, social influence and perceived monetary value.

\section{Collectivism}

Collectivism refers to individuals who tend to take decisions and actions interdependently as a group and adhere to the moralistic values of joint effort and expecting to have group rewards (Omar and Nurdin, 2015). Collectivist are those who define themselves from the social and collective aspects of the self-concept are described with the term collectivism (LeFebvre and Franke, 2013). The collectivist expects other in-group members to look after them and protect them in exchange for unquestioning loyalty (Orji, 2016).

\section{Individualism}

A society that has loose ties between each individuals is the definition of Individualism, in which everyone that participate in that society is expected to look after their immediate family only (Brewer and Venaik, 2011). Individualism also promotes a view of the self as self-directed, autonomous, and separate from others (Santos, Varnum \& Grossman, 2017). Individualist tends to draw separate line between the self and others which personal autonomy and responsibility, rather than group identification (León \& Finkelstein, 2011).

\section{Objective Knowledge}

Objective knowledge defined as actual knowledge that individual own and what they actually know (Joris, Koen, Wim \& Hurlenboeck, 2011; Janmaimool and Khajohnmanee, 2019). It provides accurate information about certain things and stored in their memory for a long time period (Gambaro, Ellis \& Prieto 2013). Thus, Objective knowledge explain how much an individual knows about a certain phenomenon (Han, 2019). 


\section{Subjective Knowledge}

Subjective knowledge is a knowledge that is personal, perceived and self assesed knowledge (Joris, Koen, Wim \& Hurlenboeck, 2011). In Addition, it is about people's own perception of understanding and how an individual thinks he or she knows about a certain product (Han, 2019; Janmaimool and Khajohnmanee, 2019). Subjective knowledge through empirical testing is reported to be an important part of knowledge because it affects individual perceptions about how to process an information (Viot, 2012). Subjective knowledge also defined as a kind of knowledge that self-reported and it reflects the individual valuation about what and how much he or she know about the environment (Ahmad \& Nordin, 2014).

\section{Environmental Awareness}

Environmental awareness can be is a formation of environmental sensitivity, that obtained by learning, understanding and behaving accordingly to the theory and reality of environmental conditions (Garcia and Luansing, 2016; Saricam and Sahin,2015). Environmental awareness can be considered as one of the prerequisites in environmental protection and an important indicator in realizing systemic progress in social-environmental relations (Du, Wang, Brombal, Moriggi, Sharpley \& Pang, 2018). Through environmental awareness, people can participate in increasing protection and achieving environmental sustainability (Abbas and Singh, 2014).

\section{The Role of Government}

Government is defined as those who have exclusive authority and capacity in a particular area, in their jurisdiction they impose legally to bind and sanction government or non-governmental actors, such as in politics or markets (Kourula, Moon, Salles-Djelic \& Wickert, 2019). Government has an important role to execute their functions in distribution, allocation and stabilization (Kharisma and Pirmana, 2013). The role of government is explained normatively and qualitatively through concepts such as community participation, equality, empowerment, and transparency, the results of this role have an impact on two sustainable dimensions, namely economic and ecological factors (Van der Waldt, 2016).

\section{Media Exposure}

Media defined as a tool that effectively facilitates the information dissemination, the information provided by media influence lifestyle and creates needs of a person (Ann, Balanza \& Tindowen 2019). The media has democratizing influences by providing platform for more people to access information and knowledge and therefore have the potential to shape public agenda (Luedecke \& Boykof, 2017).

\section{Environmental Attitude}

Environmental Attitude can be defined as a collection of beliefs, affective intentions, and also behavioral intentions that a person believe regarding any activity or issues related to the environment (Hebel, Montpied \& Fontanieu, 2014). Environmental attitudes are commonly perceived as preconditions for achieving environmental behavior. Environmental Attitudes are generally described as preconditions that is used to achieve environmental behavior. (Trop and Eilam, 2012). Environmental Behavior can be defined as a registered changes of act in a society towards the environment, ecosystem, and climate that connected with human activity (Krajhanzl, 2010).

\section{Product Attitude}

Product can be defined as anything that can be marketed and offered to a market which it can or might satisfy the market's wants and needs (Lonardo \& Soelasih, 2014). Attitude is an inclination to 
behave toward a certain object so as to throw it away or keep it, in some ways it is also a set of personal understanding whether an object is either good or bad (Yap, Komalasari \& Hadiansah, 2016). Product attitude refers to consumer preferences for specific products that influence consumer product purchasing decisions. Therefore, Product Attitude is the inclination of consumer towards specific products (Yao \& Huang, 2017).

\section{Social Influence}

Social influence refers to when people manipulate, modify and change their thoughts, perception, feelings, and behavior in order to response and conforms their social and surroundings (Varshneya, Pandey \& Das, 2017). The result of Social Influence research found that people who are in the same social group have a tendency to behave the same as others (Pan, Hou \& Liu, 2017). Social Influence can be measured by comparing pre-existing behaviors and Intention, then providing exposure to attitude, behavior or ways of communication of individuals or groups have and measuring the individual's post exposure attitude and behavior (Kim and Hollingshead, 2015).

\section{Perceived Monetary Value}

Perceived price is the subjective perception that customer had of what is sacrificed to obtain the product because customers often fail to remember the product actual price, rather they will subjectively refer those prices as expensive or cheap derived from the actual objective price (Shintaputri and Wuisan, 2017). Thus, Perceived Value can be defined as an overall assessment that conducted by consumers about a product based on what they received and what given price perception. (Gan \& Wang, 2017).

\section{Relationship between Collectivism and Environmental Attitude}

People in Collectivist culture think tend to think as a collective part in their society in order to protect the environment, therefore they can help to maintain the health and wellness of the society. The collectivism is reported has positive effects to internal environmental attitudes, indicating that consumers seek the product that result in environmental advantages (Kaufmann, Hans, Panni \& Orphanidou, 2012). Collectivist people tend to prioritize their group goals rather than their own goals, therefore they are likely to develop environmental attitude. Because of their cooperative behavior, collectivist is found to be a good predictor in forming the environmental attitude (Samarasinghe, 2012). Previous study stated that there are a positive impact between collectivism and consumers recycling behavior, the result show that collectivist have greater tendency towards buying environmental friendy product (Rizwan, Hasan, Danish \& Ali, 2017). Positive association between collectivist and environmental attitudes was repeatedly confirmed on previous empirical study (Leonidou, Leonidou \& Kvasova, 2010). Previous studies done by researchers suggest that there is a positive association between collectivism and environmental attitude (Sreen, Purbey \& Sadarangani, 2018). Therefore, based on the previous studies (Rizwan, Hasan, Danish \& Ali, 2017; Leonidou, Leonidou \& Kvasova, 2010; Sreen, Purbey \& Sadarangani, 2018; Samarasinghe, 2012; Joonas and Ruiz, 2015; Ansari and Siddiqui, 2019), it can be hypothesized that there is a significant positive effect between collectivism and environmental attitude in this research.

$\mathrm{H}_{1}$ : There is a positive relation between Collectivism and Environmental Attitude

\section{Relationship between Collectivism and Product Attitude}

Collectivists are likely to consult with their families, friends or groups to consider their opinion and advice before purchasing products. Consumers' under collectivist culture may prefer products for symbolic purpose and purchase products that represent status or reassert the similarity of their reference group (Nayeem, 2012). For example, in the situation of buying an automobile, a collectivist may seek the opinion from family and friends regarding what information to collect and which type 
of sources are valuable to use. Therefore, based on the previous study (Chen, Chen \& Tung, 2018; Zuniga and Torres, 2014; Noh, Lee, Kim \& Garrison, 2013; Kirmani \& Khan, 2016; Hutahaean \& Kurnia, 2019; Lee, 2017), this study suggested that collectivism have positive effects on product attitude.

$\mathrm{H}_{2}$ : There is a positive relation between Collectivism and Product Attitude

\section{Relationship between Individualism and Environmental Attitude}

Individualists are more focused on the personal benefits, they may behave to protect and be environmentally friendly to feel better about themselves (Cho, Thyroff, Rapert, Park \& Lee, 2013). A society that consists mainly of individualists tends to focus only on features such as design and performance (Nayeem, 2012). Individualistic person tends to put greater importance towards the relation between their own needs and their behavior rather than the implication towards others, and in that sense it will possibly impact their environmental attitude in a negative way (Kim, 2011). Prior studies (Ramayah, Lee \& Mohamad, 2010; Eom, Kim, Sherman \& Ishiji, 2016; Gumelar, 2018; Zeng, Jiang \& Yuan, 2020; Cho, Thyroff, Raper, Park \& Lee, 2013) have indicated that Individualism negatively affects environmental attitude.

$\mathrm{H}_{3}$ : There is a negative relation between Individualism and Environmental Attitude

\section{Relationship between Individualism and Product Attitude}

Consumers that considered as individualistic are more into knowing about the function and capabilities of a product before they make a decision about the product, and the behavior that exist in those kind of consumers will affect their preferences toward the product with the most functional benefits and they are generally not worried about the prestige or the social status in their decisions. (Nayeem, 2012). Several studies (Ramayah, Lee \& Mohamad, 2010; Chen, 2013; Chen, Chen \& Tung, 2018; Shavitt \& Barner, 2020; Nayeem, 2012) have reported that, individualists indicate positive attitude toward brand or product.

$\mathrm{H}_{4}$ : There is a positive relation between Individualism and Product Attitude

\section{Relationship between Objective Knowledge and Environmental Attitude}

Objective knowledge is a type of Environmental knowledge that is based on the amount of "real" knowledge of environmental protection (Kim, Kim \& Thapa, 2018). This knowledge consists of facts that are accurate and specific in an event related to the environment (Ahmad and Nordin, 2014). Literacy about green products and its effect to the environment also become a significant influence to consumer attitude tendencies towards the environment, hence implying awareness amongst all consumers about the importance of environment is very crucial to form an appropriate mindset and attitude towards green products. (Mamun, Fazal, Ahmad, Yacoob \& Mohamad, 2018). Therefore, based on previous studies (Noor, Jamil, Mat, Mat, Kasim, Muhammad \& Salleh, 2012; Taufique, Siwar, Chamburi \& Sarah, 2015; Kim, Kim \& Thapa, 2018; Ma'ruf, Surya \& Appriliany, 2016; Zheng, Xu, Kong, Deng \& Lin, 2018), there is a positive influence that Objective Knowledge to Environment Attitude.

$\mathrm{H}_{5}$ : There is a positive relation between Objective Knowledge and Environmental Attitude

\section{Relationship between Subjective Knowledge and Product Attitude}

Hadar, Sood \& Fox (2013) obtained that the subjective knowledge of consumer is strongly connected to product related experience. A research about the influence that subjective knowledge and objective knowledge have on attitudes, motivations and consumptions of organic food has concluded that subjective knowledge has a positive affect towards confidence in individual knowledge, but it also has a stronger effect on consumer attitude on a product (Aertens, Mondelaers, Verbeke, Buysse \& Huylenbroeck, 2011). Subjective Knowledge positively and also significantly affects the Product 
attitude (Paladino and Ng, 2012). Therefore, based on previous studies (Paladino and Ng, 2012; Chen, 2013; Wulandari, Rahyuda \& Yasa, 2015; Nordin \& Ahmad. 2013; Peschel et al., 2016), this study hypothesized that Subjective Knowledge has a positive and significant effect on Product Attitude.

$\mathrm{H}_{6}:$ There is a positive relation between Subjective Knowledge and Product Attitude

\section{Relationship between Environmental Awareness and Environmental Attitude}

To have better understanding in Environmental Attitude, the level of people's knowledge of environmental conditions and problems as well as their reactions and interactions with nature must be attained through environmental awareness (Ogunbode \& Arnold, 2012). The results of previous studies (Saricam and Sahin, 2015; Aral, Bayram \& Celik, 2017; Maichum, Parichatnon \& Peng 2017; Khaola, Potiane \& Mokhethi, 2014; Bala, 2016) reported that both Environmental Awareness and attitudes are mutually influenced by each other and consistency exist among them most of the time.

$\mathrm{H}_{7}$ : There is a positive relation between Environmental Awareness and Environmental Attitude

\section{Relationship between Environmental Awareness and Product Attitude}

Consumers' awareness of the environment is increasing worldwide. Hence, many companies started to produce and create products that are environmentally friendly and have a smaller adverse effect on the environment (Hojnik et al., 2019). The increasing environmental awareness makes changes in consumers' consuming behavior to purchase more ecofriendly products (Siddique and Hossain, 2018). In another study, the influences of environment awareness and product attitude were investigated (Assarut and Srisuphaolarn, 2012). Thus, based on previous studies (Chen et al., 2010; Srinivas, 2015; Mustikaningrum, 2018; Assarut and Srisuphaolarn, 2012; Kirmani \& Khan, 2016; Khaola, Potiane \& Mokhethi, 2014), this study hypothesized that product attitudes positively affected by environmental awareness.

$\mathrm{H}_{8}$ : There is a positive relation between Environmental Awareness and Product Attitude

\section{Relationship between Government's Role and Environmental Attitude}

The Government played pivotal role in preserving and protecting the environment through their regulation and implementation that directly protect and solve the environmental problems (Kulin and Seva, 2019). The role of government control and command influences consumer consumption patterns by integrating and coordinating the use of products that have an impact on the environment (Nezakati, Foreidouni \& Rahman, 2016). The Government through their function also promoting environmental awareness and consciousness among state citizen (Olalekan, 2019). On Behalf of Environmental, The Government need to facilitate and regulate actions to protect the Environment. Hence, The Governance through their instruction and protocol have to ensure the people behave in favor of environmental protection (Van der Waldt, 2016). Therefore, based on previous studies (Tan and Lau, 2010; Gadenne, Sharma, Kerr \& Smith, 2011; Kulin \& Seva, 2019; Khozani \& Dolatabadi, 2016; Jan , 2019), it can be hypothized that Government's Role affects Environmental Attitude.

$\mathrm{H}_{9}$ : There is a positive relation between Government's Role and Environmental Attitude

\section{Relationship between Government's Role and Product Attitude}

A research about the significant effect that role of campaign has to promote local product in Indonesia has found that the government marketing campaigns have some influence on individual behavior towards certain products through campaign exposures in the form of messages inside the content of the campaigns (Salehudin, 2016). Governments and authorities have also raised concerns about the environment, therefore they have ratified a significant amount of regulations in order to 
protect the environment, hence all of these regulations basically can influence the consumers to use environmentally friendly products and make environmentally friendly products more interesting for the consumer (Kianpour, Anvari, Jusoh \& Othman, 2014). Therefore, based on previous studies (Jan, Ji \& Yeo, 2019; Norazah, 2015; Chen, Chen \& Tung, 2018; Salehudin, 2016; Khozani \& Dolatabadi, 2016), it can be hypothesized that the role of government influences a positive impact towards product attitude.

$\mathrm{H}_{10}$ : There is a positive relation between The Role of Government and Product Attitude

\section{Relationship between Media exposure and Environmental Attitude}

Some researchers have agreed upon the conclusion that media exposure has taken a major role in spreading messages and information about the environment that can affect the Individual towards the environment and their pro-environmental attitude (Qader \& Zainuddin, 2011; Han \& Xu, 2020). Advertising through media platforms of sustainable products to capture customer's attention has been used toward sustainable products (Kianpour, Anvari, Jusoh \& Othman, 2014). Therefore, media has a significant role in delivering and spreading information that is relevant to their audiences, strengthening individual relationships, strengthening collective relationships, and helped in the building of environment attitude (Trivedi, Patel \& Acharya, 2018). Therefore, based on previous studies (Trivedi, Patel \& Acharya, 2018; Han and Xu, 2020; Qader and Zainuddin, 2011; Qader and Zainuddin, 2010; Xu \& Han, 2019; Williams, 2011), it can be hypothized that media exposure influences a positive impact towards environmental attitude.

$\mathrm{H}_{11}$ : There is a positive relation between Media Exposure and Environmental Attitude

\section{Relationship between Environmental Attitude and Purchase Intention}

Individuals that have positive attitude towards the environment will make them motivated to purchase or consume the product. The environmental attitude has significantly positive influence on individual's purchase intention (Maichum, Parichatnon \& Peng, 2017). A consumer may purchase eco-friendly products because they have a positive or favorable attitude on eco-friendly product (Koloba, 2020). Some researchers have also mentioned that consumers with high environmental attitude have an intention to purchase products that are considered to be friendly towards the environment (Onurlubas, 2018). Individuals who are sensitive to the environment tend to change their behavior and purchase products that are environmentally friendly (Leonidou, Leonidou \& Kvasova, 2010). Various researchers also showed that there is a significant and positive relation between environmental attitude and the consumer purchase behavior towards eco-friendly product, it showed that one of the important determinants of a person's motivation to pay for green products is environmental attitude. It can be assumed that there is an existed and strong relationship between positive attitude towards the environment and the purchase intention on green products. Therefore, based on previous studies, (Sharma and Aswal, 2017; Kim, 2011; Chen, 2013; Huang, Yang \& Wang, 2014; Indriani, Rahayu \& Hadiwidjojo, 2019; Barber et al, 2012; Mei, Ling \& Piew, 2012), it can be hypothesized the relationships between environment attitude and green purchase intention is significant.

$\mathrm{H}_{12}$ : There is a positive relation between Environmental Attitude and Purchase Intention

\section{Relationship between Product Attitude and Purchase Intention}

Products that have environmental ethical and features represented in purchasing attitudes, intentions and behavior. Products Attitude has important factor in forming individual purchase intention, because when individual gives a positive and negative assessment to a product, the possibility of how to respond to a product and their purchasing plan is based on their assessment of the products attitude (Yu \& Lee, 2019). Consumers would evaluate and then purchase a product based on preferred preferences of product attributes, the consumers making purchase decisions that product 
attitude would directly affect consumers' purchase intention. Therefore, based on previous studies (Yao and Huang, 2017; Kaushal \& Kumar, 2019; Vidyanata, Sunaryo \& Hadhiwidjojo, 2018; Adis \& Jun, 2013; Gomathy and Rajan, 2018; Kudeshia \& Kumar, 2017), product attitudes is a primary factor in purchase intention.

$\mathrm{H}_{13}$ : There is a positive relation between Product Attitude and Purchase Intention

\section{Relationship between Social Influence and Purchase Intention}

The result of recent studies showed that the attitude towards a brand has an influence on consumer intention to purchase a product and influence by social norms, belief, and expectations also have an effect towards the purchase intention of consumer. If a product has a good impression and experience from consumers or their friends. Consumers will base on them and it will lead to positive word of mouth communication to others. Therefore, the consumers who are likely to share positive word of mouth will increase the purchase intention of others (Wong, 2019). The tendency of consumers to communicate their experience of something that is consumptive to peers can highly influence the attitude towards the product or service. their decision is in the form of buying or avoiding buying products in order to be like peers (Akar, Yuksel \& Bulut, 2015). Prior researches (Wong, 2019; Akar, Yuksel \& Bulut, 2015; Ali, 2018; Hashim, 2018; Ayensa, Mosquera \& Murillo, 2016; Lasuin and Ching, 2014; Rompas and Tumewu, 2014) have found that social influence has positive effect on Purchase Intention of consumers.

$\mathrm{H}_{14}$ : There is a positive relation between Social Influence and Purchase Intention

\section{Relationship between Perceived Monetary Value and Purchase Intention}

Perceived value is important because it may increase consumers' interest in purchasing specific products, hence, the company can increase the consumer's purchase intention by increasing perceived value (Dhewi, Putra, Soeharto \& Wahyudi, 2018). Perceived Monetary Value has affected the consumer's purchasing decisions, the relation between Perceived Monetary Value and Purchase intention has shown that consumers will purchase products with high perceived value. The probability of consumers' Purchase intention will increase when consumers obtain more benefits than they pay for a product (Phan and Mai, 2016). Thus, if consumers receive high perceived value of products or services, it will create a good brand image and brand loyalty, which can lead to a positive effect on their purchase intention. Therefore, based on previous studies (Phan \& Mai, 2016; Zulfikar \& Mayvita, 2018; Saputri and Kurniawati, 2015; Setiawan and Achyar, 2012; Rafsandjani, 2018; Naami, 2017; Pham, Tran, Misra, Maskeliunas \& Damasevicius, 2018; Vazifehdoost and Sagheb, 2018), it can be hypothesized that perceived monetary value and purchase intention has a significant positive relation.

$\mathrm{H}_{15}$ : There is a positive relation between Perceived Monetary Value and Purchase Intention

\section{Research Model}

The modified CAB's model postulate nine conceptually independent determinants of customer's purchase intention of green products: collectivism, individualism, objective knowledge, subjective knowledge, environmental awareness, government's role, media exposure, social influence, and perceived monetary value. This model is applied to prove the establishment of purchase intention of green product. Based on this model, value cognitive according to collectivism, individualism, objective knowledge, environmental awareness, and government's role influence environmental attitude, whereas collectivism, individualism, subjective knowledge, environmental awareness, and government's role influence product attitude. At the end, these two along with social influence and perceived monetary value will lead to and influenced purchase intention (Chen, Chen \& Tung, 2018). The research model will be shown on Figure 1 below. 


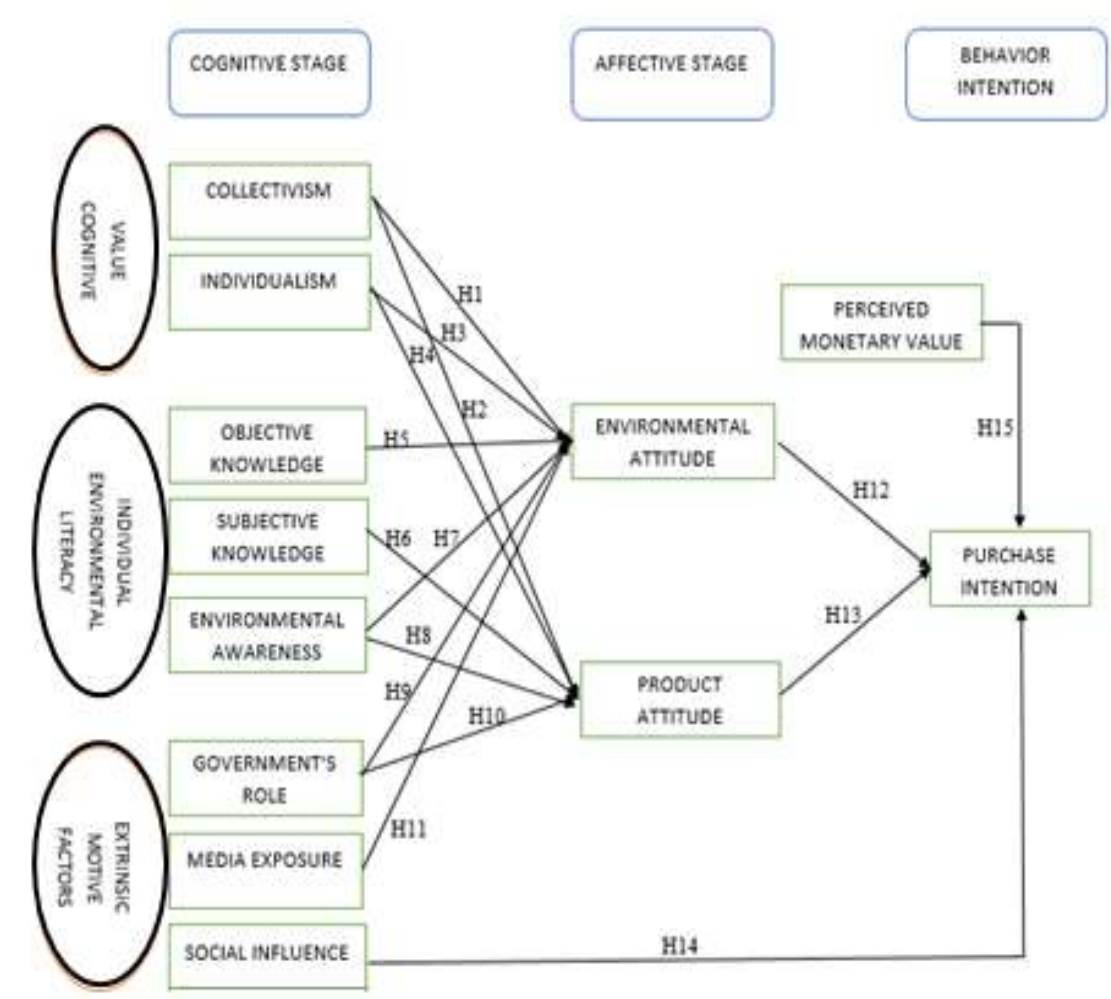

Chen, Chen \& Tung (2018)

Source:

Figure 1. Research Model

\section{Methods}

\section{Design Sample}

This research applied convenience sampling as the sampling design. There are several reasons for the chosen design sampling. First, this study is about green products. There is no specific brand was asked, only about people perception and knowledge about green products. Green products are not a new phenomenon but becomingly part of lifestyle. Second, convenience sampling has main advantages such as quick results, convenience, and less expensive (Sekaran \& Bougie, 2016).

\section{Sample Size}

This study uses SMART PLS for its data analysis. Noordzij, Tripepi, Dekket, Zoccali, Tanck \& Jager (2010) define the sample size as the number of experimental units used in a research, and one of the first practical steps in designing a trial is the choice of the sample size needed to answer the research question (Noordzij, Tripepi, Dekket, Zoccali, Tanck \& Jager, 2010). In this study, 300 respondents were found appropriate because according to Roscoe (1975, cited by Sekaran \& Bougie, 2016) the amount of sample size for social science research is usually between 30-500.

\section{Measurement Scale}

This study uses Likert Scale to measure each indicator. According to Joshi, Khale, Chandel and Pal (2015) Likert Scale is a set of items that researchers offer for a real or hypothetical situation under research, in which the participants are asked to choose their level of agreements arranging from strongly disagree to strongly agree on a metric scale. The combination of statements will reveal the 
specific attitudes that participants have towards the issue (Joshi, Kale, Chandel \& Pal, 2015). All research indicators were based on previous research (i.e., Chen, Chen, \& Tung, 2018).

\section{Results and Discussion}

\section{Response Rate}

The data for this research was collected through internet questioner in which the researcher distributed the questioner to 300 respondents and obtained 262 respondents for this research. Therefore, the response rate for this research was $87 \%$. The result concluded that $32.8 \%$ of the total respondents are aged between 11-20 years old, $29.4 \%$ are aged between $21-30$ years old, $11.8 \%$ are aged between 31-40 years old, 21\% are aged between 41-50, and the rest are aged between 51-60 years old. Also, $56.5 \%$ of the total respondents that participate in this research are female and the rest of the respondents which is $43.5 \%$ of the total respondents that participate in this research are male.

\section{Realiability and Validity}

Reliability and validity tests were performed before hypotheses testing. In this research, Cronbach Alpha was applied in order to assess reliability analysis to all the measures used. Table 2 indicates that the results of Cronbach's Alpha of all variables were above 0.6 which surpass the acceptable value of Cronbach Alpha that ranging from 0.6 and 0.8 (Hajjar, 2018). Also, 0.6-0.7 Cronbach Alpha level indicates an acceptable reliability and with 0.8 or greater value of Cronbach Alpha is considered a very good reliability level (Ursachi, Horodnic \& Zait, 2015). The validity of the test can also be seen in Table 4.1. The result shows that all of AVE (Average Variance Extracted) is higher than 0.4 because AVE of 0.4 or greater is still considered as acceptable (Huang, Wang, Wu \& Wang, 2013). Also, according to Muhamad and Noor (2016) if AVE value ranging from 0.4 to 0.5 but the Composite Reliability is higher than 0.6 then the convergent validity is acceptable. The result of AVE and Composite Reliability in Table 2shows that the convergent validity has reached the acceptable standard.

Table 2. Reliability and Validity Tests

\begin{tabular}{|c|c|c|c|c|c|}
\hline \multirow[b]{2}{*}{ Variable and Indicators } & \multicolumn{3}{|c|}{ Reliability } & \multicolumn{2}{|c|}{ Validity } \\
\hline & $\begin{array}{l}\text { Corrected } \\
\text { Item-Total } \\
\text { Correla- } \\
\text { tion }\end{array}$ & $\begin{array}{l}\text { Cronbach' } \\
\text { s Alpha }\end{array}$ & $\begin{array}{l}\text { Compo- } \\
\text { site Relia- } \\
\text { bility }\end{array}$ & $\begin{array}{l}\text { AVE } \\
(>0.4)\end{array}$ & $\begin{array}{c}\text { Outer } \\
\text { Loading } \\
(>0.7 \\
0.5<x<0.7) \\
\text { Acceptable }\end{array}$ \\
\hline $\begin{array}{l}\text { Collectivism } \\
\text { 1. I am an individual who attaches im- } \\
\text { portant towards the environmental pro- } \\
\text { tection in Indonesia }\end{array}$ & 0.650 & & & & 0.682 \\
\hline $\begin{array}{l}\text { 2. Even if green products have a more ex- } \\
\text { pensive price tag than regular product, I } \\
\text { will still choose to purchase green prod- } \\
\text { ucts }\end{array}$ & 0.639 & 0.692 & 0.815 & 0.525 & 0,721 \\
\hline $\begin{array}{l}\text { 3. I will share the benefits of green products } \\
\text { with everyone }\end{array}$ & 0.550 & & & & 0,810 \\
\hline $\begin{array}{l}\text { 4. The purchase of green products can help } \\
\text { reduce the amount of pollution in the en- } \\
\text { vironment of Indonesia }\end{array}$ & 0.660 & & & & 0,677 \\
\hline $\begin{array}{l}\text { Individualism } \\
\text { 1. The purchase of green product is a form } \\
\text { respect towards the environment }\end{array}$ & 0.529 & 0.656 & 0.812 & 0.592 & 0,832 \\
\hline
\end{tabular}




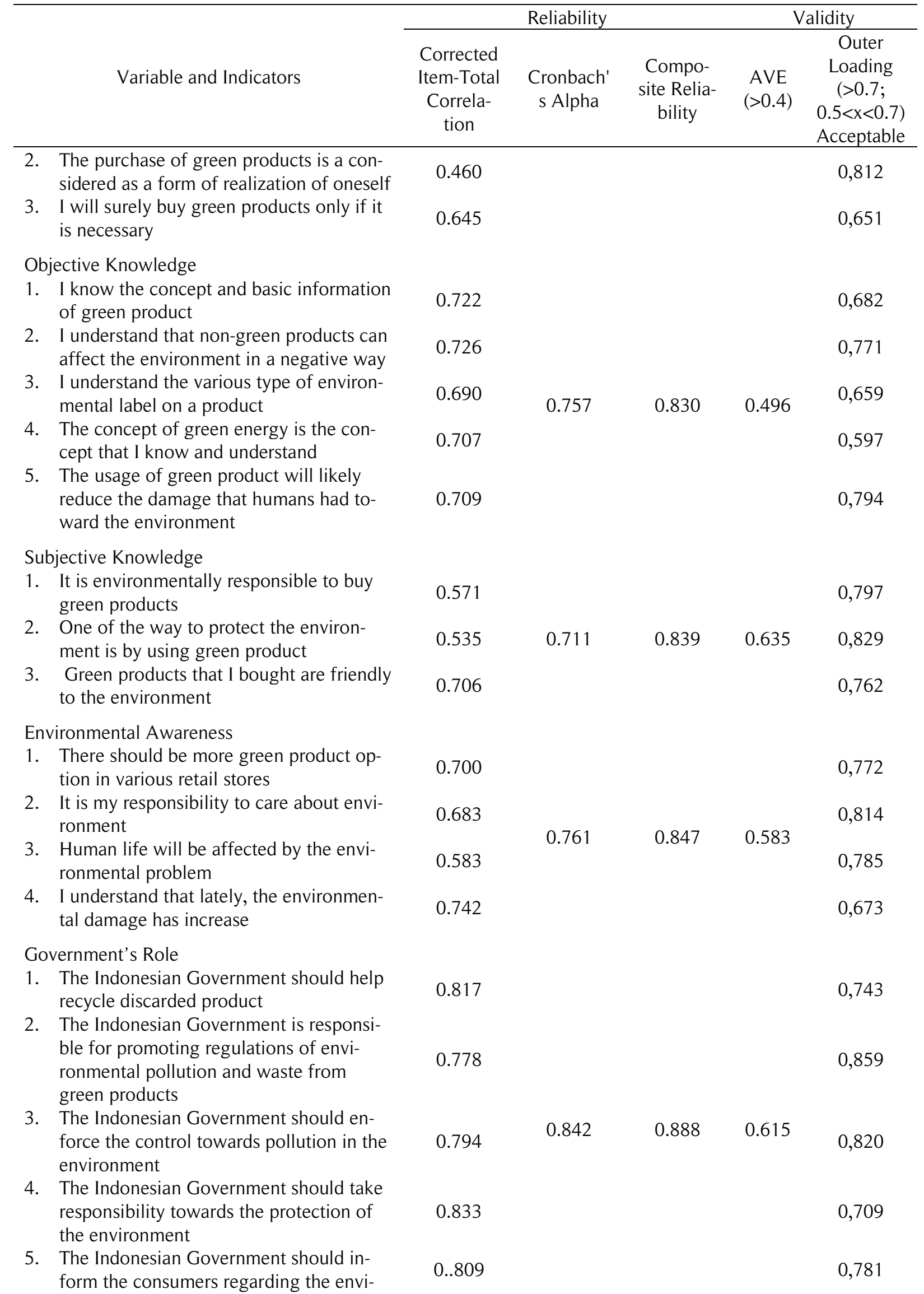




\begin{tabular}{|c|c|c|c|c|c|}
\hline \multirow[b]{2}{*}{ Variable and Indicators } & \multicolumn{3}{|c|}{ Reliability } & \multicolumn{2}{|c|}{ Validity } \\
\hline & $\begin{array}{l}\text { Corrected } \\
\text { Item-Total } \\
\text { Correla- } \\
\text { tion }\end{array}$ & $\begin{array}{l}\text { Cronbach' } \\
\text { s Alpha }\end{array}$ & $\begin{array}{l}\text { Compo- } \\
\text { site Relia- } \\
\text { bility }\end{array}$ & $\begin{array}{l}\text { AVE } \\
(>0.4)\end{array}$ & $\begin{array}{c}\text { Outer } \\
\text { Loading } \\
(>0.7 ; \\
0.5<x<0.7) \\
\text { Acceptable }\end{array}$ \\
\hline \multicolumn{6}{|l|}{$\begin{array}{l}\text { ronmental knowledge and environmental } \\
\text { protection }\end{array}$} \\
\hline \multicolumn{6}{|l|}{ Media Exposure } \\
\hline $\begin{array}{l}\text { 1. Information about green products are } \\
\text { available in online or offline newspaper }\end{array}$ & 0.811 & \multirow{3}{*}{0.815} & \multirow{3}{*}{0.876} & \multirow{3}{*}{0.704} & 0,894 \\
\hline $\begin{array}{l}\text { 2. Information and commercials about } \\
\text { green products are available on TV }\end{array}$ & 0.791 & & & & 0,847 \\
\hline $\begin{array}{l}\text { 3. Information and commercials about } \\
\text { green products are available on the radio }\end{array}$ & 0.691 & & & & 0,771 \\
\hline \multicolumn{6}{|l|}{ Social Influence } \\
\hline $\begin{array}{l}\text { 1. The knowledge about green product that } \\
\text { I had is influenced by my friends. }\end{array}$ & 0.830 & \multirow{7}{*}{0.843} & \multirow{7}{*}{0.879} & \multirow{7}{*}{0.509} & 0,681 \\
\hline $\begin{array}{l}\text { 2. The knowledge about green product that } \\
\text { I had is influenced by my family }\end{array}$ & 0.822 & & & & 0,722 \\
\hline $\begin{array}{l}\text { 3. I will also buy green products if my } \\
\text { friends purchase green product }\end{array}$ & 0.813 & & & & 0,746 \\
\hline $\begin{array}{l}\text { 4. I will also buy green products if my } \\
\text { friends purchase green product }\end{array}$ & 0.825 & & & & 0,709 \\
\hline $\begin{array}{l}\text { 5. I will share the information of green } \\
\text { products to all of my friends }\end{array}$ & 0.850 & & & & 0,648 \\
\hline $\begin{array}{l}\text { 6. The majority of my friends purchase } \\
\text { green products }\end{array}$ & 0.813 & & & & 0,745 \\
\hline $\begin{array}{l}\text { 7. The majority of my family purchase } \\
\text { green products }\end{array}$ & 0.813 & & & & 0,739 \\
\hline \multicolumn{6}{|l|}{ Perceived Monetary Value } \\
\hline $\begin{array}{l}\text { 1. The price of green products are consid- } \\
\text { ered to be economical }\end{array}$ & 0.817 & \multirow{3}{*}{0.837} & \multirow{3}{*}{0.892} & \multirow{3}{*}{0.735} & 0,731 \\
\hline $\begin{array}{l}\text { 2. The value of green products are in line } \\
\text { with the value that it offers to the con- } \\
\text { sumer }\end{array}$ & 0.792 & & & & 0,917 \\
\hline $\begin{array}{l}\text { 3. The price of green products are consid- } \\
\text { ered to be acceptable }\end{array}$ & 0.686 & & & & 0,910 \\
\hline \multicolumn{6}{|l|}{ Environmental Attitude } \\
\hline $\begin{array}{l}\text { 1. It is necessary to advocate an environ- } \\
\text { mentally lifestyle }\end{array}$ & 0.820 & \multirow{4}{*}{0.860} & \multirow{4}{*}{0.905} & \multirow{4}{*}{0.705} & 0,835 \\
\hline $\begin{array}{l}\text { 2. Promoting consumers' attention towards } \\
\text { environmental issues is very important }\end{array}$ & 0.809 & & & & 0,862 \\
\hline $\begin{array}{l}\text { 3. It is considered to be very crucial to con- } \\
\text { trol the amount of pollution in the envi- } \\
\text { ronment }\end{array}$ & 0.804 & & & & 0,864 \\
\hline $\begin{array}{l}\text { 4. The scarcity of resources on earth, made } \\
\text { the protection of the environment be- } \\
\text { came very important }\end{array}$ & 0.849 & & & & 0,795 \\
\hline \multicolumn{6}{|l|}{ Product Attitude } \\
\hline $\begin{array}{l}\text { 1. I would use green products rather than } \\
\text { non-green products }\end{array}$ & 0.879 & \multirow[t]{2}{*}{0.895} & \multirow[t]{2}{*}{0.920} & \multirow[t]{2}{*}{0.657} & 0,771 \\
\hline 2. I am pleased to purchase green product & 0.865 & & & & 0,851 \\
\hline
\end{tabular}




\begin{tabular}{|c|c|c|c|c|c|}
\hline \multirow[b]{2}{*}{ Variable and Indicators } & \multicolumn{3}{|c|}{ Reliability } & \multicolumn{2}{|c|}{ Validity } \\
\hline & $\begin{array}{c}\text { Corrected } \\
\text { Item-Total } \\
\text { Correla- } \\
\text { tion }\end{array}$ & $\begin{array}{c}\text { Cronbach' } \\
\text { s Alpha }\end{array}$ & $\begin{array}{l}\text { Compo- } \\
\text { site Relia- } \\
\text { bility }\end{array}$ & $\begin{array}{l}\text { AVE } \\
(>0.4)\end{array}$ & $\begin{array}{c}\text { Outer } \\
\text { Loading } \\
\quad(>0.7 ; \\
0.5<x<0.7) \\
\text { Acceptable }\end{array}$ \\
\hline
\end{tabular}

3. Green product can reduce the amount of energy that I will use and this is an im-

portant consideration for me

4. Green products that can reduce the damage towards the environment are important to me

5. I'm willing to obtain green products that have a good impact towards the environment

6. Recyclable products are nice

Purchase Intention

1. I will buy green products in the near future,

2. In the future, I plan to buy green products

3. I will buy green products in line with government policy

4. I am very likely to purchase green product in the near future

0.780

Source: data analysis (2020)

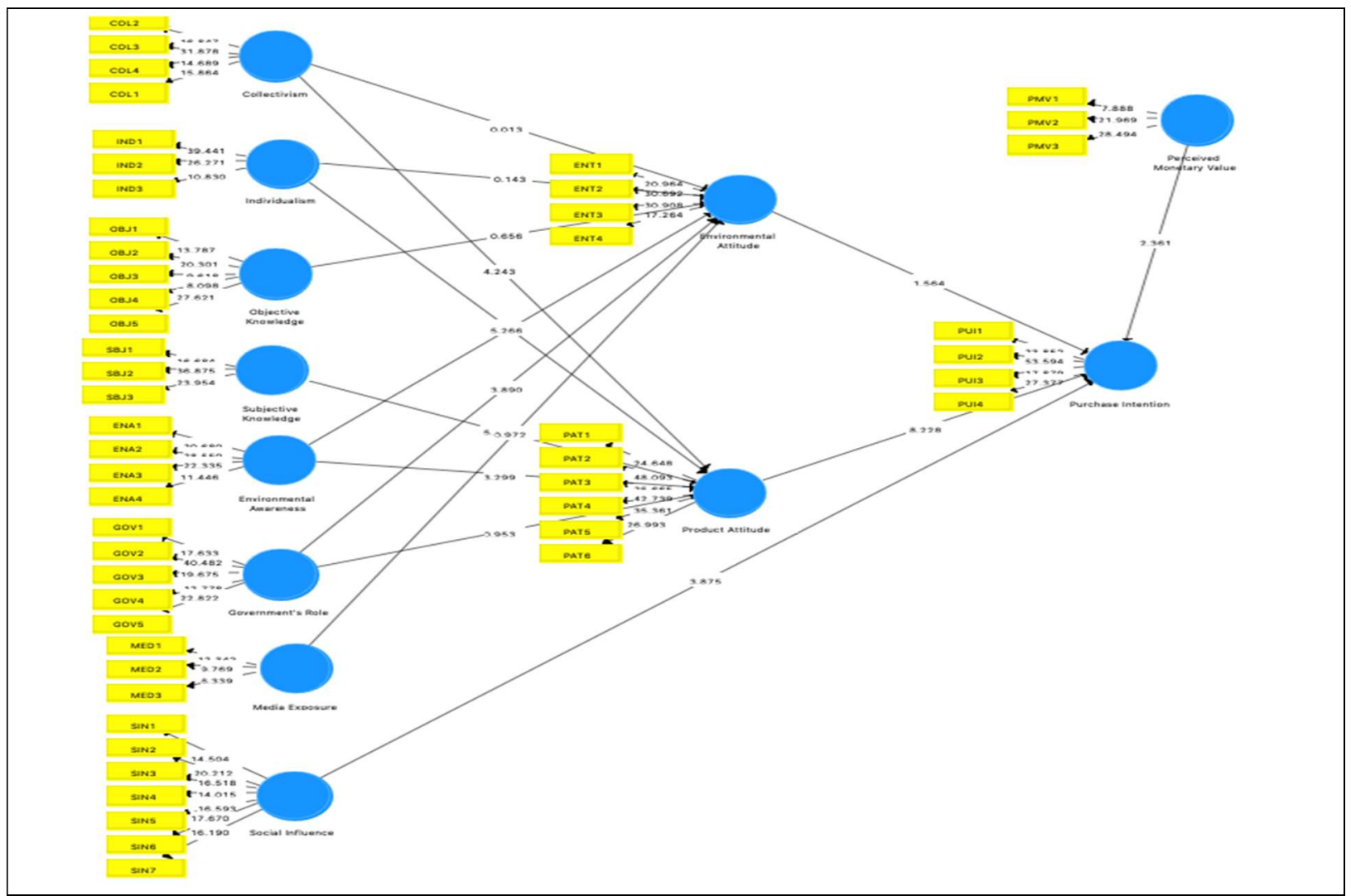

Figure 2. Outer Model 


\section{Hypotheses Testing}

Hypothesis Testing should be done to measure its significance of the hypotheses has been given before. It can be conducted with T statistics $>1.96$ and P-value $<0.05$. Table 3 shows there are fifteen hypotheses in the table that give a significant effect.

Table 3. Hypothesis Testing Result

\begin{tabular}{|c|c|c|c|c|}
\hline Hypothesis & $\begin{array}{l}\text { Standard- } \\
\text { ized Coeffi- } \\
\text { cient }\end{array}$ & $\begin{array}{c}\text { T- } \\
\text { Value }\end{array}$ & $\begin{array}{c}\text { P- } \\
\text { Value }\end{array}$ & Hypothesis \\
\hline H1: Collectivism has an effect on Environmental Attitude & 0.001 & 0,013 & 0,989 & Unsupported \\
\hline H2: Collectivism has an effect on Product Attitude & 0.266 & 4,243 & 0,000 & Supported \\
\hline H3: Individualism has an effect on Environmental Attitude & 0.010 & 0,143 & 0,886 & Unsupported \\
\hline H4: Individualism has an effect on Product Attitude & 0.087 & 1,341 & 0,181 & Unsupported \\
\hline $\begin{array}{l}\text { H5: Objective Knowledge has an effect on Environmental } \\
\text { Attitude }\end{array}$ & 0.046 & 0,656 & 0,512 & Unsupported \\
\hline $\begin{array}{l}\text { H6: Subjective Knowledge has an effect on Product Atti- } \\
\text { tude }\end{array}$ & 0.300 & 5,087 & 0,000 & Supported \\
\hline $\begin{array}{l}\text { H7: Environmental Awareness has an effect on Environ- } \\
\text { mental Attitude }\end{array}$ & 0.459 & 5,266 & 0,000 & Supported \\
\hline $\begin{array}{l}\text { H8: Environmental Awareness has an effect on Product } \\
\text { Attitude }\end{array}$ & 0.217 & 3,299 & 0,001 & Supported \\
\hline $\begin{array}{l}\text { H9: Government's Role has an effect on Environmental At- } \\
\text { titude }\end{array}$ & 0.271 & 3,890 & 0,000 & Supported \\
\hline H10: Government's Role has an effect on Product Attitude & 0.053 & 0,953 & 0,341 & Unsupported \\
\hline $\begin{array}{l}\text { H11: Media Exposure has an effect on Environmental Atti- } \\
\text { tude }\end{array}$ & 0.045 & 0,972 & 0,332 & Unsupported \\
\hline $\begin{array}{l}\text { H12: Environmental Attitude has an effect on Purchase In- } \\
\text { tention }\end{array}$ & 0.115 & 1,564 & 0,118 & Unsupported \\
\hline H13: Product Attitude has an effect on Purchase Intention & 0,571 & 8,228 & 0,000 & Supported \\
\hline \multirow{2}{*}{$\begin{array}{l}\text { H14: Social Influence has an effect on Purchase Intention } \\
\text { H15: Perceived Monetary Value has an effect on Purchase } \\
\text { Intention }\end{array}$} & 0,231 & 3,875 & 0,000 & Supported \\
\hline & $-0,126$ & 2,361 & 0,019 & Supported \\
\hline
\end{tabular}

Source: data analysis (2020)

Structural model or inner model used in this analysis to describe the relationship between the variables and the measuring indicators. To evaluate structural model, this research uses $\mathrm{R}^{2}$ path coefficient, original sample, and p-value.

Table 4. $\mathrm{R}^{2}$ Values for Actual Test

\begin{tabular}{lcc}
\hline \multicolumn{1}{c}{ Variables } & R Square & R Square Adjusted \\
\hline Environmental Attitude & 0,516 & 0,505 \\
Product Attitude & 0,598 & 0,591 \\
Purchase Intention & 0,545 & 0,538 \\
\hline
\end{tabular}

Source: data analysis (2020)

\section{Discussion}

This research aimed to test a model of consumers and purchase intention, involving CAB model. The results show that out of 15 hypotheses that were conducted, there are 7 hypotheses that are not supported. The firts hypothesis stated that there is a significant relationship between collectivism 
and environmental attitude as stated in Kaufmann, Hans, Panni and Orphanidou (2012), Samarasinghe (2012), Rizwan, Hasan, Danish and Ali (2017), Leonidou, Leonidou and Kvasova(2010), Sreen, Purbey and Sadarangani (2018). However, the result in Table 3 suggests that the hypothesis is not supported. Thus in this study, collectivism for creating environmental attitude is not supported. Indonesia as a collective society hasn't been able to establish and developed a good collective culture in terms of environmental attitude to reduce the environmental damage, because Indonesia as a nation has one of the most polluted environment in the world (Akhtar \& Soetjipto, 2014). The other reason is considering that the collectivist though has a strong sense of responsible to the related group or family, nevertheless they may believe that making differences in the environment for their immediate family members are difficult to be establish (Cho, Thyroff, Rapert, Park \& Lee, 2013).

The second hypothesis stated thathere is a significant relationship between collectivism and product attitude. This study supported the previous research such as Nayeem (2012), and Chen, Chen and Tung (2018). The third hypothesis related to the significant relationship between individualism and environmental attitude as stated in Kim (2011), Ramayah, Lee and Mohamad (2010). However, the results suggest that the hypothesis is not supported. Thus in this study, individualism for creating environmental attitude is not supported. Individualism makes people care about their need more than what others need in terms of environmental attitude and the result is people tend to perceive their own self-centered needs and disregard what others might need including approach to the more environmentally friendly manner (Lee, 2017). These results are in line with previous findings, people with individualism culture argue that recycling to help environment reduce its emission is less important for individual to do because it has no effect towards their own life and they might feel that climate change is intractable and that it couldn't be solved by their individual actions. Their value towards the environment are negatively related to belief about environmental attitude including resource conservation (Kim, 2011; Xiang, Zhang, Geng, Zhou \& Wu, 2019).

The fourth hypothesis stated thatthere is a significant relationship between individualism and product attitude as stated in Nayeem, 2012; Ramayah, Lee \& Mohamad, 2010. However, the result suggests that the hypothesis is not supported. Thus in this study, individualism for creating product attitude is not supported. Individualism tend to put themselves first and fulfill their own needs, and in order to satisfy their needs they tend to stick with their own believes and mindset about certain product that they might choose regardless if it is environmentally friendly or even not environmentally friendly because the decisions of individualists are not depend on family members, peers or social groups, they will rely on internal knowledge based on their personal experiences, they will look for new experiences to expand their knowledge and will not be affected by external factors (Lee, 2017 ; LeFebvre and Volker, 2013 ; Yin, Wang, Xia \& Gu, 2019). Individualists will not worry about social status or prestige when they make a purchasing decision, they will only focus on the performance of a product (Nayeem, 2012). As this research found that individualism did not have a statistically significant relationship with either environmental attitude nor product attitude, because out of 262 respondents, 235 respondents responded that they only buy environmentally friendly products if it is necessary, which means they still have to think about their needs before they think about preserving the environment. The research also found that 210 out of 262 people think that the environmental product is still more of a self-realization and they don't consider it as a basic necessity in order to preserve nature.

The fifth hypothesis stated that there is a significant relationship between objective knowledge and environmental attitude as stated in Mamun, Fazal, Ahmad, Yacoob and Mohamad (2018), Noor, Jamil, Mat, Mat, Kasim, Muhammad and Salleh (2012). However, the hypothesis is not supported. Thus in this study, objective knowledge for creating environmental attitude is not supported. There are 45 people in this study that did not know about the environmental label and 61 people that did not know about the concept renewable energy and its effect towards the environment, from this data we know that the quite a lot of respondents are still poorly equipped with 
the right knowledge about preserving the environment in order for them to developed their environmental attitude. The other reason is that the research about behavior regarding green products found the same result that the objective knowledge did not significantly affect environmental attitude (Lin and Huang, 2012).

The sixth hypothesis related to the significant relationship between subjective knowledge and product attitude. The result of this study confirm previous research such as Hadar, Sood and Fox (2013), Aertens, Mondelaers, Verbeke, Buysse and Huylenbroeck (2011) and Paladino and Ng (2012). The seventh hypothesis stated that there is a significant relationship between environmental awareness and environmental attitude. This result supported the study of Sarcicam and Sahin (2015). Table 3 also shows that the eight hypothesis which relates to the significant relationship between environmental awareness and product attitude. This result supported the study of Assarut and Srisuphaolarn (2012). Furthermore, the ninth hypothesis that stated the significant relationship between government's role and environmental attitude was also supported. This result confirms the study of Van der Waldst (2016).

The tenth hypothesis stated that there is a significant relationship between Government's Role and Product Attitude as stated in Kianpour, Anvari, Jusoh, and Othman (2014). However, the result suggest that the hypothesis is not supported. Thus in this study, Government's role for creating product attitude is not supported. Indonesian government are allowed to make regulations relating environmental and it can deliver precautions to people in order to convince people to live more environmentally friendly, but Indonesia cannot really impose a strict rule in order to enhance consumer attitude towards eco-friendly product because Indonesia has not got any formal institution that focused on the eco-friendly product, so the amount of attitude regarding eco-product is very low and government programs towards eco-friendly products has not been improved yet because of this reason (Gou, 2020). The other reason is that the government effort in a green way is still new, there is not available knowledge about consumer behavior in terms of green products purchasing (Nezakati, Hosseinpour \& Hassan, 2014).

The eleventh hypothesis proposed that there is a significant relationship between media exposure and environmental attitude as stated in Trivedi, Patel, and Acharya (2018). However, the results i suggest that the hypothesis is not supported. Thus in this study, Media Exposure for creating environmental attitude is not supported. Media in Indonesia has not been effective in terms of spreading the knowledge and precautions that leads to the development of environmental attitude (Assegaff, Kurniabudi \& Hendri, 2016 \& Assegaff, Hendri, Sunoto \& Yani, 2017), because 47\% of the total respondent claimed that they never heard on their television such advertisement that encourage them to strengthen their attitude towards the environment and the similar result can be seen with online media and radio with each contribute $30.9 \%$ and $55.3 \%$ towards the same statement. The other reason that can explained the media influence towards the environmental attitude is that previous study has questioned about the role of Media in influencing Environmental concern and opposed that due to consumers' skepticism, media may not play a significant role in forming environmental attitude (Trivedi, Patel \& Acharya, 2018).

The twelfth hypothesis stated that there is a significant relationship between environmental attitude and purchase intention. However, the result suggests that the hypothesis is not supported. Thus in this study, environmental attitude in creating purchase intention is not supported. The environmental attitude in Indonesia's society is still poor and has not yet been developed properly, because most of the respondent know about environmental issues but they don't have the attitude to help the environment (Akhtar and Soetjipto, 2014), and it reflects in this study that majority of the respondents considered that they will only buy green products if it was necessary. Considering environmental attitude do not influence the purchase intention toward environmentally-friendly products (Setyawan, Noermijati, Soenaryo \& Aisjah, 2018)

The thirteenth hypothesis porposed that there is a significant relationship between product attitude and purchase intention. The results connfirm the hypothesis and also confirms the previous 
study by Yu and Lee (2019), and Yao and Huang (2017). The fourteenth hypotesis refers to the significant relationship between social influence and purchase intention. The findings confirm the hypothesis and supports previous study of Wong (2019) and Akar et al. (2015). Finally, the findings also support the last hypothesis that suggest there is a significant relationship between perceived monetary value and purchase intention. This results confirm previous study of Dhewi, Putra, Soeharto and Wahyudi (2018) and Phan and Mai (2016).

\section{Conclusion}

The result of the study concludes about the important issues relating purchase intention establishment from a different perspective. Eight out of fifteen hypotheses are supported for each mediating variable. Environmental awareness and government's role influence environmental attitude, whereas collectivism, subjective knowledge, and environmental awareness have an influence on product attitude. However, collectivism, individualism, objective knowledge, and media exposure are found not to have effects on environmental attitude. This might be due to lack of caring and sense of belonging and also the minimal information that builds environmental attitude in Indonesia. Also, individualism and government's role are found not to have effects on product attitude. This might be due to the preference of the product that each individual has and cannot be interfered by outside influence.

This research has two main limitations. First, this research is a cross-sectional study. In other words, this research only describe the phenomenon at that time with that context. Second, this research applied a non-probability design sampling. Thus, the results of this study can not be generalized to explain Indonesian consumer purchase intention on green products. Those two limitations may suggest that future research may apply an enhance the study by integrating longitudinal studies and probability design sampling.

\section{References}

Abbas, M.Y., Singh, R. (2014). A Survey of Environmental Awareness, Attitude and Participation Amongst University Students: A Case Study. International Journal of Science and Research (IJSR). 3. 1755-1760.

Adis, A. A. \& Jun, K. (2013). Antecedents of Brand Recall and Brand Attitude towards Purchase Intention in advergames. European Journal of Business and Management, 5, $58-67$.

Aertens, J., Mondelaers, K., Verbeke, W., Buysse, J., Huylenbroeck, G. V. (2011). The influence of subjective and objective knowledge on attitude, motivations and consumption of organic food. British Food Journal, 113, 1353-1378.

Ahmad, T. B. T., Nordin, M. S. (2014). University Students' Subjective Knowledge of Green Computing and Pro-Environmental Behavior. International Education Studies, 7, 64-74, doi:10.5539/ies.v7n2p64.

Akar, E., Yüksel, H., Bulut, Z. (2015). The Impact of Social Influence on the Decision-Making Process of Sports Consumers on Facebook. Internet Uygulamaları ve Yönetimi Dergisi, 6, 5-27.

Ansari, M. \& Siddiqui, D. (2019). Effects of Culture on Green Purchase Intention, the Mediating Role of New Ecological Paradigm, Environmental Collective Efficacy and Environmental Knowledge. SSRN Electronic Journal, 5,1- 33.

Ann, M., Balanza, A., Tindowen, D. J. (2019). The Effects of Media Exposure to Students' Core Values. International Journal of Humanities, Social Sciences and Education, 6, 1-10.

Aral, N., Bayram, N., Celik, C. (2017). A Study of Relationship between Environmental Awareness and Environmental Attitudes among High School Students. International Journal of Recent 
Advances in Organizational Behaviour and Decision Sciences (IJRAOB) An Online International Research Journal, 3, 948- 955.

Assarut, N. \& Srisuphaolarn, P. (2012). Determinants of green product purchase intentions: The roles of environmental consciousness and product attributes. ChulalongKom, 32, 108-122.

Assegaff, S., Kurniabudi., Hendri. (2016). Social Media Success for Knowledge Sharing: Instrument Content Validation. International Journal of Electrical and Computer Engineering (IJECE), 6, 2447-2453. 10.11591/ijece.v6i5.10556.

Assegaff, S., Hendri., Sunoto, A., Yani, H., Kisbiyanti, D. (2017). Social Media Success Model for Knowledge Sharing (Scale Development and Validation). Telkomnika (Telecommunication Computing Electronics and Control), 15, 1335-1343. 10.12928/TELKOMNIKA.v15i3.5569.

Ayensa, E. J., Mosquera, A., Murillo, Y. S. (2016). Omnichannel Customer Behavior: Key Drivers of Technology Acceptance and Use and Their Effects on Purchase Intention. Frontiers in Psychology, 7, 1- 11.

Bala, R. (2016). Study of Environment Awareness in Relation to Attitude Towards Environment Among Secondary School Students. Indian Journal of Research, 5, 236-237.

Baiquni, A.M \& Ishak, A. (2019). The green purchase intention of Tupperware products: the role of green brand positioning. Jurnal Siasat Bisnis, 23, 1-14.

Barber, Nelson \& Kuo, Pei-Jou \& Bishop, Melissa \& Goodman, Raymond. (2012). Measuring psychographics to assess purchase intention and willingness to pay. Journal of Consumer Marketing, 29, 280-292.

Brewer, Paul \& Venaik, Sunil. (2011). Individualism-Collectivism in Hofstede and GLOBE. Journal of International Business Studies, 42, 436-445.

Chen, C. C., Chen, C. W., Tung, Y. C. (2018). Exploring the Consumer Behavior of Intention to Purchase Green Products in Belt and Road Countries: An Empirical Analysis. Sustainability, 10, 854-872.

Chen, L. (2013). A Study of Green Purchase Intention Comparing with Collectivistic (Chinese) and Individualistic (American) Consumers in Shanghai, China. Information Management and Business Review, 7, 342-346.

Chen, T. B. \& Chai, L. T. (2010). Attitude towards the Environment and Green Products: Consumers' Perspective. Management Science and Engineering, 2, 27-39.

Cho, Y. N., Thyroff, A., Rapert, M., Park, S. Y., Lee, H. (2013). To be or not to be green: Exploring individualism and collectivism as antecedents of environmental behavior. Journal of Business Research, 66, 1052-1059.

Du, Y., Wang, X. Y., Brombal, D., Moriggi, A., Sharpley, A., Pang, S. (2018). Changes in Environmental Awareness and Its Connection to Local Environmental Management in Water Conservation Zones: The Case of Beijing, China. Sustainability, 10, 2087.

Dhewi, T. S., Putra, I. W. J. A., Soeharto., Wahyudi, H. D. (2018). The Influence of Green Perceived Value and Green Perceived Risk Perceptions on the Green Product Purchase Intention. KnE Social Sciences, 3, 411-425.

Eom, K., Kim, H. S., Sherman, D. K., Ishiji, K. (2016). Cultural Variability in the Link Between Environmental Concern and Support for Environmental Action. Psychological Science, 27, 1331-1339. 
Gadenne, D., Sharma, B., Kerr, D., Smith, T. (2011). The influence of consumers' environmental beliefs and attitudes on energy saving behaviours. Energy Policy, 39, 7684-7694.

Gambaro, A., Ellis, A.C., Prieto, V. (2013). Influence of Subjective Knowledge, Objective Knowledge and Health Consciousness on Olive Oil Consumption-A Case Study. Food and Nutrition Sciences, 4, 446-453, doi:10.4236/fns.2013.44057.

Gan, C., Wang, W. (2017). The influence of perceived value on purchase intention in social commerce context. Internet Research, 4, 772-785.

Garcia, E.C., Luansing, B. (2016). Environmental Awareness among sellect Graduating College Students in Region IVA. LPU-Laguna Journal of Multidisciplinary Research, 5, 106-119.

Gomathy M. \& Rajan K. K. S. (2018). Influence of Brand Attitude on Purchase Intention of Modular Kitchen in Chennai City. J Account Mark, 7, 1-3, doi: 10.4172/2168-9601.1000300.

Gou, Z. (2020). Green Building in Developing Countries: Policy, Strategy, and Technology. Springer Nature, Switzerland.

Gumelar, G., Vania, a., Maulana, H. (2018). Do Cultural Styles Predict Pro-Environment Behaviour among Slum-area Resident of Jakarta?. E3S Web of Conferences, 68, 1-5.

Hadar, L., Sood, S., Fox, C. (2013). Subjective Knowledge in Consumer Financial Decisions. Journal of Marketing Research, 50, 303-316.

Hajjar, S. T. E. (2018). Statistical Analysis: Internal-Consistency Reliability and Construct Validity. International Journal of Quantitative and Qualitative Research Methods, 1, 27-28.

Han, T. I. (2019). Objective knowledge, subjective knowledge, and prior experience of organic cotton apparel. Han Fast Text, 6, 1-15. https://doi.org/10.1186/s40691-018-0168-7.

Han, R. \& Xu, J. (2020). A Comparative Study of the Role of Interpersonal Communication, Traditional Media and Social Media in Pro-Environmental Behavior: A China-Based Study. International Journal of Environmental Research and Public Health, 17, 1-21.

Haque, A., Anwar, N., Yasmin, F., Sarwar, A., Ibrahim, Z., Momen, A. (2015). Purchase Intention of Foreign Products: A Study on Bangladeshi Consumer Perspective. SAGE, 1-12. doi: 10.1177/2158244015592680.

Hashim, N. H., Yahya, W. K. Bakar, S. A. Asrul, S. A. (2018). Social influence and eco-label factors towards purchase intention of home products: A PLS approach. Journal of Emerging Economies \& Islamic Research, 6, 39-47.

Hebel, F. L., Montpied, P., \& Fontanieu, V. (2014). What Can Influence Students' Environmental Attitudes? Results from a Study of 15-year-old Students in France. International Journal of Environmental \& Science Education, 9, 329-345.

Hojnik, J., Ruzzier, M., Konečnik Ruzzier, M. (2019). Transition towards Sustainability: Adoption of Eco-Products among Consumers. Sustainability, 11, 1-29.

Huang, C. C., Wang, Y. M., Wu, T. W., Wang, P. A. (2013). An Empirical Analysis of the Antecedents and Performance Consequences of Using the Moodle Platform, International Journal of Information and Education Technology, 2, 217-221.

Huang, Y. C., Yang, M., Wang, Y. C. (2014). Effects of Green Brand on Green purchase intention. Marketing Intelligence \& Planning, 32, 251- 268. 
Hutahaean C.I. \& Kurnia P. R. (2019). Influence of Non-demographic Factors on Indonesian Consumers Purchase Intention Towards Green Products. ASEAN Marketing Journal, 6, 63-80.

Indriani, I. A. D., Rahayu, M., Hadiwidjojo. D. (2019). The Influence of Environmental Knowledge on Green Purchase Intention the Role of Attitude as Mediating Variable. International Journal of Multicultural and Multireligious Understanding, 6, 627-635.

Jaafar, S., Lalp, P.E. \& Naba, M. M. (2012). Consumers' perception, attitudes and purchase intention towards private label food products in Malaysia. Asian Journal of Business and Management Sciences, 2, 73-90.

Jan, I. \& Ji, S. \& Yeo, C. (2019). Values and Green Product Purchase Behavior: The Moderating Effects of the Role of Government and Media Exposure. Sustainability, 11, 1-16.

Janmaimool, P., Khajohnmanee, S. (2019). Roles of Environmental System Knowledge in Promoting University Students' Environmental Attitudes and Pro-Environmental Behaviors. Sustainability, 11, 1-18.

Joonas, K. \& Ruiz, D. D. (2015). Examining the Impact of Collectivism on Environmental Beliefs and Attitudes of Business Students: A Cross-cultural Study. AIMS, 1, 17-34.

Joris, A., Koen, M., Wim, V., Hurlenbroeck, G. V. (2011). The influence of subjective and objective knowledge on attitude, motivations and consumption of organic food. British Food Journal, 113, 1353-1378. doi: 10.1108/00070701111179988.

Joshi, A., Kale, S., Chandel, S., Pal, D. K. (2015). Likert Scale: Explored and Explained. British Journal of Applied Science \& Technology, 7, 396-403.

Kaufmann, Hans R., Panni, M. F. A. K., Orphanidou, Y. (2012) Factors Affecting Consumers' Green Purchasing Behavior: An Integrated Conceptual Framework. The Bucharest University of Economic Studies, 31, 50-69.

Kaushal, S. \& Kumar, Rakesh. (2019). Influence of attitude towards advertisement on purchase intention: Exploring the mediating role of attitude towards brand using SEM approach. The IUP journal of marketing management, 15, 45- 59.

Khaola, P.P., Potiane, B., Mokhethi, M. (2014). Environmental Concern, Attitude Towards Green Products and Green Purchase Intentions of Consumers in Lesotho. Ethiopian Journal of Environmental Studies \& Management, 7, 361-370.

Kharisma, B., Pirmana, V. (2013). The Role of Government on Education Quality and its Provision: The Case of Public Junior Secondary School among Provinces in Indonesia. European Journal of Social Sciences, 37, 259-270.

Khozani, A. S. \& Dolatabadi, H. R. (2016). The role of government, industry, and culture of resistive economy in people's attitude to purchase Iranian brand products. Marketing and Branding Research, 3, 14-23.

Kianpour, K., Anvari, R., Jusoh, A., Othman, M. F. (2014). Important Motivators for Buying Green Products. Intangible Capital, 10, 873-896.

Kim, M. S., Kim, J. W., Thapa, B. (2018). Influence of Environmental Knowledge on Affect, Nature Affiliation and Pro environmenral behaviors among tourists. Sustainability, 10, 1-16, doi:10.3390/su10093109.

Kim, Y. (2011). Understanding Green Purchase: The Influence of Collectivism, Personal Values and Environmental Attitudes, and the Moderating Effect of Perceived Consumer Effectiveness. Seoul Journal of Business, 1, 65-92. 
Kim, Y. J., Hollingshead, A. (2015). Online Social Influence: Past, Present, and Future. Communication Yearbook, 39, 163-192.

Kirmani, M. D. \& Khan, M. N. (2016). Environmental Concern to Attitude Towards Green Products: Evidences From India. Serbian Journal of Management, 11, 159 - 179.

Koloba, H. (2020). Purchase Intention towards Environmentally Friendly Products among Consumers in South Africa. Applying The Theory of Planned Behaviour, 12, 1309-8047.

Kourula, A., Moon, J. Salles-Djelic, M. L., Wickert, C. (2019). New Roles of Government in the Governance of Business Conduct: Implications for Management and Organizational Research. Organization Studies, 8, 1101- 1123.

Krajhanzl, Jan. (2010). Environmental and Proenvironmental Behavior. Health Education: International Experiences, 12, 221-274.

Kulin, J., Sevä, I. J. (2019). The Role of Government in Protecting the Environment: Quality of Government and the Translation of Normative Views about Government Responsibility into Spending Preferences. International Journal of Sociology, 49, 110-129, doi: 10.1080/00207659.2019.1582964

Kudeshia, C. \& Kumar, A. (2017). Social eWOM: Does it affect the brand attitude and purchase intention of brands?. Management Research Review. 40. 310-330.

Lasuin, C. A. \& Ching, N. Y. (2014). Factors Influencing Green Purchase Intention among University Students. Malaysian Journal of Business and Economics, 1, 1- 14.

Lee, Y. K. (2017). A Comparative Study of Green Purchase Intention between Korean and Chinese Consumers: The Moderating Role of Collectivism. Sustainability, 9, 1930.

León, M. C. D. \& Finkelstein, M. A. (2011). Individualism/Collectivism and Organizational Citizenship Behavior. Psicothema, 3, 401-406.

LeFebvre, Rebecca \& Franke, Volker. (2013). Culture Matters: Individualism vs. Collectivism in Conflict Decision-Making. Societies, 3, 128-146.

Leonidou, L., Leonidou, C., Kvasova, O. (2010). Antecedents and Outcomes of Consumer Environmentally-Friendly Attitudes and Behavior. Journal of Marketing Management, 26, 13191344.

Lin, P. C., Huang, Y. H. (2012). The Influence Factors on Choice Behavior Regarding Green Products Based on the Theory of Consumption Values. Journal of Cleaner Production, 22, 11-18.

Lonardo \& Soelasih, Y. (2014). Analisis Pengaruh Kualitas Produk, Harga, dan Lingkungan Fisik Perusahaan Kue Lapis Legit XYZ Terhadap Kepuasan Konsumen Dalam Membangun Word of Mouth Positif. Jurnal Manajemen, 1, 27-40.

Luedecke. G. \& Boykof, M. T. (2017). Environment and The Media. The Internasional Encyclopedia of Geography, 1, doi: 10.1002/9781118786352.wbieg0464.

Madahi, A. \& Sukati, I. (2012). The Effect of External Factors on Purchase Intention amongst Young Generation in Malaysia. International Business Research, 5, 154- 159.

Maichum, K., Parichatnon, S., \& Peng, K. (2017). The Influence of Environmental Concern and Environmental Attitude on Purchase Intention towards Green Products: A Case Study of Young Consumers in Thailand. International Journal of Business Marketing and Management, 2, 1-8. 
Mamun A. A., Fazal, S. A., Ahmad G.B., Yaacob, M. R. B., Mohamad, R. (2018). Willingness to Pay for Environmentally Friendly Products among Low-Income Households along Coastal Peninsular Malaysia. Sustainability, 10, 1- 19, 1316, doi:10.3390/su10051316.

Ma'ruf, Surya, S., Appriliany, P. D. (2016). Knowledge, Attitudes and Behavior of University Students towards Environmental Issues in Indonesia. Sains Humanika, 8, 81-88.

Mei, O. J, Ling, K. W. Piew, T. H. (2012). The Antecedents of Green Purchase Intention among Malaysian Consumers. Asian Social Science, 8, 248- 263.

Mittal, R. \& Mittal, C. G. (2013). Impact of Population Explosion on Environment. WeSchool "Knowledge Builder"-The National Journal, 1, 1-5.

Muhamad, S. L. \& Noor A. M. A. (2016). Confirmatory Factor Analysis Approach: A Case Study of Mathematics Students' Achievement in TIMSS. Malaysian Journal of Mathematical Sciences, 10, 41- 51.

Mustikaningrum, H. (2018). The Effect of Environmental Awareness on Consumer Behavior of Ecofriendly Products Mediated by Eco-friendly Attitude. RJOAS, 7, 270-278.

Naami, A., Rahimi, Z., Ghandvar, P. (2017). The Effect of Perceived Value, Perceived Risk, and Price on Customers Buying Intention (Case Study: Employees of Presov Electronics Company). International Review of Management and Marketing, 7, 164-170.

Nayeem, T. (2012). Cultural Influences on Consumer Behaviour. International Journal of Business and Management, 7, 78-91.

Nezakati, H., Foreidouni, M. A., Rahman. A. A. (2016). An Evaluation of Government Role in Green Supply Chain Management through Theories. International Journal of Economics and Financial Issues, 6, 76-79.

Nezakati, H., Hosseinpour, M., Hassan M. H., (2014). Government Concerns of Consumers' Intention to Purchase Green Products (Preliminary Study-Malaysia Evidence). Journal of Applied Sciences, 14, 1757-1762.

Nia, B., Rinawati, D., Hery, S., Bayu, D. (2018). The Effect of Green Purchase Intention Factors on The Environmental Friendly Detergent Product (Lerak). E3S Web of Conferences. 73. 1-5.

Noh. M., Lee, K., Kim, S., Garrison, G. (2013). Effects of Collectivism on Actual S-commerce Use and The Moderating Effect of Price Consciousness. Journal of Electronic Commerce Research, 14, 244-260

Noor, N. A. M., Jamil, C. Z. M., Mat, N., Mat, N., Kasim, A., Muhammad, A., \& Salleh, H. S. (2012). The Relationships between Environmental Knowledge, Environmental Attitude, and Subjective Norm on Malaysian Consumers Green Purchase Behaviour. Malaysian Journal of Consumer and Family Economics, 15, 1-20.

Noordzij, M., Tripepi, G., Dekket, F. W., Zoccali, C., Tanck, M. W., Jager, K. J. (2010). Sample size calculations: basic principles and common pitfalls. Nephrol Dial Transplant, 25, 1388-1393.

Norazah, M. S. (2015). Consumer environmental concern and green product purchase in Malaysia: structural effects of consumption values. Journal of Cleaner Production, 132, 204-214.

Ogunbode, C. A., Arnold, K. (2012). A Study of Environmental Awarenessand Attitudes in Ibadan, Nigeria, Human and Ecological Risk Assessment. An International Journal, 3, 669-684.

Okada, Erica \& Mais, Eric. (2010). Framing the "Green" alternative for environmentally conscious consumers. Sustainability Accounting, Management and Policy Journal, 1, 222-234. 
Olalekan, R. M., Omidiji, A. O., Williams, E. A. (2019). The roles of all tiers of government and development partners in environmental conservation of natural resources: a case study in $\mathrm{Ni}-$ geria. MOJ Eco Environ Sci, 4, 114-121, doi: 10.15406/mojes.2019.04.00142.

Omar, Safiah \& Noordin Fauziah. (2015). Moderator Influences on Individualism-Collectivism and Career Adaptability among ICT Professionals in Malaysia. Procedia Economics and Finance, 37, 529-537.

Onurlubas, E. (2018). The Mediating Role of Environmental Attitude on the Impact of Environmental Concern on Green Product Purchasing Intention. Emerging Market Journals, 8, 5- 18, doi: 10.5195/emaj.2018.158.

Orji, Rita. (2016). Persuasion and Culture: Individualism-Collectivism and Susceptibility to Influence Strategies. In: Persuasive Technology, 31-19.

Paladino, A., Ng, S. (2012). An examination of the influences on 'green' mobile phone purchases among young business students: an empirical analysis. Environmental Education Research, 19, 118-145.

Pan, X., Hou, L., Liu, K. (2017). Social influence on selection behaviour: Distinguishing local- and global-driven preferential attachment. PLOS ONE, 12, 1-11.

Patel, C., \& Chugan, P. K., (2015) The Influence of Consumer Perception Towards Green Advertising on Green Purchase Intention. International Journal of Entrepreneurship \& Business Environment Perspectives, 3, 1865-1873.

Pei Kian, T., Boon, G., Wee, L. F. S., Yeow, J. (2017). Factors that Influence the Consumer Purchase Intention in Social Media Websites. International Journal of Supply Chain Management, 6, 208- 214.

Peschel, A., Grebitus, C., Steiner, B., Michele, V. (2016). How does consumer knowledge affect environmentally sustainable choices? Evidence from a cross-country latent class analysis of food labels. MPRA, 69864, 1-41.

Pham, Q. T., Tran, X., Misra, S., Maskeliunas, R., Damasevicius, R. (2018). Relationship between Convenience, Perceived Value, and Repurchase Intention in Online Shopping in Vietnam. Sustainability, 10, 1- 14.

Phan, T., Mai, P. (2016). Determinants Impacting Consumers' Purchase Intention: The Case of Fast Food in Vietnam. International Journal of Marketing Studies, 8, 56-68.

Qader, I. K. \& Zainuddin, Y. (2010). Intention to Purchase Green Electronic Products: The Consequences of Perceived Government Legislation, Media Exposure and Safety \& Health Concern and the Role of Attitude as Mediator. International Journal of Innovation, Management and Technology, 1, 432- 440.

Qader, I. K. \& Zainuddin, Y. (2011). The Impact of Media Exposure on Intention to Purchase Green Electronic Products amongst Lecturers. International Journal of Business and Management, 6 (10), 240- 248.

Rafsandjani, R. F. (2018). Analyzing The Effect of Trust and Perceived Value on Purchase Intention (Case Study of Shopee). Management and Economics Journal, 2, 65-78.

Ramayah, T., Lee, J., Mohamad, O. (2010). Green product purchase intention: Some insights from a developing country. Resources, Conservation and Recycling, 54, 1419-1427. 
Rizwan, M., Hassan, M., Danish, R., Ali, A.R. (2017). Consumer's characteristics and social influence factors on green purchasing intentions. Pakistan Journal of Life and Social Sciences, 15, 24-30.

Rompas, E. P. \& Tumewu, F. J. (2014). Social Influence to Consumer Buying Decision A Qualitative Method on Samsung Galaxy Series Customers in Manado. Jurnal EMBA, 2, 727- 735.

Salehudin, I. (2016). 100\% Indonesia: Role of Government Campaign to Promote Local Products in Indonesia. ASEAN Marketing Journal. 8. 1-17.

Samarasinghe, Rohini. (2012). "The Influence of Cultural Values and Environmental Attitudes on Green Consumer Behaviour". Behavioral Science Research Institute, 1, 83-98.

Samadi, B., Loan, K., Yin-Fah, B. (2015). Exploring Customer Purchasing Intention. The Journal of business and social studies, 5, 15-23, doi: 10.18533/ijbsr.v5i5.736.

Santos, H. C., Varnum, M. E. W., \& Grossman I. (2017). Global Increases in Individualism. Psychological Science, 9, 1228-1239.

Saputri, S. M. \& Kurniawati. (2015). Pengaruh Perceived Quality dan Perceived Value Terhadap Purchase Intention. Seminar Nasional Cendekiawan 2015, 755-761.

Saricam, H., Şahin, S. (2015). The Relationship between the Environmental Awareness, Environmental Attitude, Curiosity and Exploration in Highly Gifted Students: Structural Equation Modelling. Educational Process: International Journal, 4, 7-17, doi: 10.12973/edupij.2015.412.1.

Saxena, Ravindra \& Khandelwal, Pradeep. (2012). Greening of industries for sustainable growth: An exploratory study on durable, non-durable and services industries. International Journal of Social Economics. 39. 551-586.

Setyawan, A., Noermijati, N., Sunaryo, S., Aisjah, S. (2018). Green product buying intentions among young consumers: extending the application of theory of planned behavior. Problems and Perspectives in Management, 2, 145-154.

Setiawan, R. \& Achyar, A. (2012). Effects of Perceived Trust and Perceived Price on Customers' Intention to Buy in Online Store in Indonesia. Asean Marketing Journal, 4, 26-36.

Sekaran, U. \& Bougie, R. (2016). Research Methods for Business: A Skill Building Approach. John Wiley \& Sons Ltd, United Kingdom.

Sharma, K. \& Aswal, C. (2017). "Green Purchase Intentions, Collectivism and Materialism: An Empirical Investigation". The Delhi University Journal of the Humanities and the Social Sciences, 4, 33-50.

Sharma, V., Sonwalkar, J., Kapse, M. (2013). Consumer Purchase Behaviour for Green Products. International Journal of Economics \& Business Administration, 1, 50-65.

Shavitt, S. \& Barnes, A. J. (2020). Culture and the Consumer Journey. Journal of Retailing, 96, 4054, doi: https://doi.org/10.1016/j.jretai.2019.11.009.

Shintaputri, I., Wuisan, A. J. (2017). The Impact of Perceived Price towards Perceived Value Through the Mediation of Perceived Quality: A Case of Brand X Smartphone in Indonesian Middle-Class Customers. iBuss Management, 1, $29-42$.

Siddique, M. Z. R. \& Hossain, A. (2018). Sources of Consumers Awareness toward Green Products and Its Impact on Purchasing Decision in Bangladesh. Journal of Sustainable Development, 11, 9-22. 
Sreen, N., Purbey, S., Sadarangani, P. (2018). Impact of culture, behavior and gender on green purchase intention. Journal of Retailing and Consumer Services, 41, 177-189.

Srinivas, A. (2015). Consumer Awareness and Attitude towards Environmental Products. International Journal of Advanced Scientific Technologies, Engineering and Management Sciences. 2, 13-16.

Takaya, R. (2019). Antecedents Analysis of Purchase Intention. Business and Entrepreneurial Review. Business and Entrepreneurial review, 16, 1-16.

Tan, B. C. \& Lau, T. C. (2010). Attitude towards the Environment and Green Products: Consumers' Perspective. Management Science and Engineering, 4, 27- 39.

Taufique, K. M. R., Siwar, C., Chamburi, N., Sarah, F. H. (2015). Integrating General Environmental Knowledge and Eco-Label Knowledge in Understanding Ecologically Conscious Consumer Behavior. Procedia Economics and Finance ,37,39-45.

Trivedi, R., Patel, J., Acharya, N. (2018). Causality analysis of media influence on environmental attitude, intention and behaviors leading to green purchasing. Journal of Cleaner Production, 196, 11-12.

Trop, T. \& Eilam, E. (2012). Environmental Attitudes and Environmental Behavior-Which Is the Horse and Which Is the Cart?. Sustainability, 4, 2210-2246.

Ursachi, G., Horodnic, I. A., Zait, A. (2015). How reliable are measurement scales? External factors with indirect influence on reliability estimators. Procedia Economics and Finance, 20, 679 686.

Van der Waldt, G. (2016). The Role of Government in Sustainable Development: Towards a Conceptual and Analytical Framework for Scientific Inquiry. Administratio Publica. 24. 49-72.

Varshneya, G., Pandey, S., Das, G. (2017). Impact of Social Influence and Green Consumption Values on Purchase Intention of Organic Clothing: A Study on Collectivist Developing Economy. Global Business Review, 18, 478- 492.

Vazifehdoost, H. \& Sagheb, B. (2018). Relationships of Brand Attitude and Perceived Value and Its Dimensions with Consumers' Purchase toward Luxury Brand. Case Studies Journal, 7, 5257.

Vidyanata, D., Sunaryo, Hadhiwidjojo, D. (2018). The Role of Brand Attitude and Brand Credibility as a Mediator of The Celebrity Endorsement Strategy To Generate Purchase Intention. Journal of Applied Management, 16, 402- 411.

Viot, C. (2012). Subjective knowledge, product attributes and consideration set: A wine application. International Journal of Wine Business Research, 24, 219-248.

Wang, E. (2014). Consumer characteristics, social influence, and system factors on online groupbuying repurchasing intention. Journal of Electronic Commerce Research, 5, 119-132.

Williams, A.E (2011). Media evolution and public understanding of climate science. Politics and the Life Sciences, 30, 20-30.

Wong, A. (2019). A Study of Purchase Intention on Smartphones of Post 90s in Hong Kong. Asian Social Science, 15, 78-87. 10.5539/ass.v15n6p78.

Wu, Shwu-Ing \& Chen, Yen-Jou. (2014). The Impact of Green Marketing and Perceived Innovation on Purchase Intention for Green Products. International Journal of Marketing Studies, 6, 81100. Doi: 10.5539/ijms.v6n5p81. 
Wulandari, A. A. S. A, Rahyuda, I. K., Yasa, N. N. K. (2015). The Role of Customer Attitude in Mediating Knowledge Influence Towards the Purchase Intention of Green Product. Jurnal Dinamika Manajemen. 6, 133-144.

Xiang, P., Zhang, H., Geng, L., Zhou, K., \& Wu, Y. (2019). Individualist-Collectivist Differences in Climate Change Inaction: The Role of Perceived Intractability. Frontiers in psychology, 10, 1- 12. https://doi.org/10.3389/fpsyg.2019.00187

Xu, J. \& Han, R. (2019). The Influence of Place Attachment on Pro-Environmental Behaviors: The Moderating Effect of Social Media. International Journal of Environmental Research and Public Health, 16, 1-16, doi:10.3390/ijerph16245100.

Yao, C. \& Huang, P. (2017). Effects of Placement Marketing on Product Attitude and Purchase Intention in Traditional Industry. EURASIA Journal of Mathematics, Science and Technology Education, 12, 8305-8311.

Yap, R. J. C., Komalasari, F., \& Hadiansah, I. (2016). The Effect of Financial Literacy and Attitude on Financial Management Behavior and Satisfaction. International Journal of Administrative Science \& Organization, 3, 140-146.

Yin, X. C., Wang, H. W., Xia, Q. W., Gu, Q. C. (2019). How Social Interaction Affects Purchase Intention in Social Commerce: A Cultural Perspective. Sustainability, 11, 1-18. 10.3390/su11082423.

Yu, S., Lee, J. (2019). The Effects of Consumers' Perceived Values on Intention to Purchase Upcycled Products. Sustainability. 11, 1- 20. 1034. 10.3390/su11041034.

Zeng, J., Jiang, M., Yuan, M. (2020). Environmental Risk Perception, Risk Culture, and ProEnvironmental Behavior. Int. J. Environ. Res. Public Health, 17, 1-18.

Zheng, Q. J., Xu, A. X., Kong, D. Y., Deng, H. P., Lin, Q. Q. (2018). Correlation between The Environmental Knowledge, Environmental Attitude, and Behavioral Intention of Tourists for Ecotourism in China. Applied Ecology and Environmental Research, 16, 51- 62.

Zulfikar, R. \& Mayvita, P. A. (2018). The Relationship of Perceived Value, Perceived Risk, and Level of Trust Towards Green Products of Fast Moving Consumer Goods Purchase Intention. JEMA: Jurnal Ilmiah Bidang Akuntansi dan Manajemen, 15, 85- 97.

Zuniga, M \& Torres, I. M. (2014). Influence of Collectivist and Individualist Cultural Orientation and Regulatory Construal Fit on Brand Attitudes. Global Conference on Business and Finance Proceedings, 9, 91- 93. 